No 4078

Studia nad Autorytaryzmem i Totalitaryzmem 43, nr 4 Wrocław 2021

https://doi.org/10.19195/2300-7249.43.4.25

\author{
AGNIESZKA MALICKA \\ ORCID: 0000-0003-1722-7300 \\ Uniwersytet Wrocławski \\ agnieszka.malicka@uwr.edu.pl
}

\title{
Sądy społeczne w systemie wymiaru sprawiedliwości Niemieckiej Republiki Demokratycznej
}

Słowa kluczowe: sądy społeczne, socjalistyczny wymiar sprawiedliwości, sędziowie niezawodowi, rozstrzyganie sporów.

\author{
SOCIAL COURTS IN THE JUSTICE SYSTEM \\ OF THE GERMAN DEMOCRATIC REPUBLIC
}

\begin{abstract}
Social courts in the German Democratic Republic, as constitutional judicial organs, guaranteed the direct participation of citizens in the exercise of state power. They played an important role in the judicial system and in fact became the courts of the lowest instance. They settled disputes in the field of labour and civil law and adjudicated in cases of violations of criminal law. In retrospect, they can be assessed as a special type of court typical of the socialist system, the decisions of which were primarily of educational and preventive importance.
\end{abstract}

Keywords: social courts, socialist judiciary, lay judges, dispute resolution.

\section{Wstęp}

W systemie prawa NRD przewidziany był udział tak zwanego czynnika społecznego w sprawowaniu wymiaru sprawiedliwości. Obok typowego i stosowanego w wielu państwach, także współcześnie, udziału ławników w postępowaniach 
przed sądami w NRD do systemu sądownictwa ${ }^{1}$ wprowadzono instytucję sądów społecznych $^{2}$ (gesellschaftliche Gerichte). Ich utworzenie miało gwarantować szeroko rozumiane konstytucyjne prawo obywateli do bezpośredniego uczestniczenia w sprawowaniu władzy, wynikające z art. 5 oraz art. 90 ust. 3 Konstytucji z 1968 roku $^{3}$, a także być gwarantem praworządności działania socjalistycznego państwa. Ponadto udział obywateli w wymiarze sprawiedliwości miał jednocześnie, zgodnie z postanowieniami art. 87 Konstytucji, zapewnić realizację sprawowanej przez nich funkcji społecznej kontroli nad przestrzeganiem socjalistycznego prawa ${ }^{4}$.

\section{Geneza sądów społecznych}

Pierwsza Konstytucja NRD z 1949 roku $^{5}$ nie przewidywała jeszcze istnienia sądów społecznych. Zgodnie z jej art. 126 wymiar sprawiedliwości sprawowany był wyłącznie przez Sąd Najwyższy oraz sądy landów (Gerichte der Länder), jednak z art. 130 bezpośrednio wynikał obowiązek zapewnienia jak najszerszego udziału sędziów niezawodowych w postępowaniach sądowych ${ }^{6}$. Do 1953 roku wymiar sprawiedliwości w NRD był sprawowany wyłącznie przez państwowe sądy ${ }^{7}$, natomiast od 1953 rola sądów — początkowo tylko sądów

1 System sądownictwa NRD był całkowicie upolityczniony i podlegał władzy partyjnej. Zob. m.in. H. Mahnke, Menschen- und Grundrechte in beiden Teilen Deutschlands, „Vereinte Nationen: German Review on the United Nations" 17, 1969, nr 1, s. 5, oraz opracowanie służb naukowych Bundestagu: Fragen zur DDR — Verfassung im Vergleich mit dem Grundgesetz, s. 12, https://www. bundestag.de/resource/blob/422898/cd5058f62cb62fd679b49ff115b5fc51/wd-3-151-09-pdf-data. pdf (dostęp: 16.06.2021).

2 Sądy społeczne w NRD zostały powołane na wzór wprowadzonych jeszcze w okresie leninowskim radzieckich dyscyplinarnych sądów koleżeńskich. Zob. m.in. P. Szczemielinow, Sądy koleżeńskie w ZSRR i w Federacji Rosyjskiej, „Palestra” 1961, nr 11, s. 108 n., https://bazhum.muzhp.pl/media/files/Palestra/Palestra-r2003-t47-n1_2(541_542)/Palestra-r2003-t47-n1_2(541_542)-s108-110/Palestra-r2003-t47-n1_2(541_542)-s108-110.pdf (dostęp: 20.09.2021) oraz Gesellschaftsgerichte in der DDR, [w:] Kleines kriminologisches Wörterbuch. 2. völlig neubearbeitetet und erweiterte Auflage, red. G. Kaiser, Heidelberg 1985, s. 140 n.

3 Verfassung der DDR vom 6. April 1968, GB1. I, S. 199; tekst konstytucji dostępny na stronie: http://www.verfassungen.de/ddr/verf68-i.htm (dostęp: 16.06.2021). Tłumaczenie na język polski zob. Konstytucja Niemieckiej Republiki Demokratycznej, Dresden 1968.

4 Zob. L. Janicki, Ewolucja ustroju politycznego Niemieckiej Republiki Demokratycznej, Wrocław 1974, s. 330.

${ }^{5}$ Verfassung der Deutschen Demokratischen Republik vom 7. Oktober 1949, GBl. 1949 I, S. 5, https://www.1000dokumente.de/index.html?c=dokument_de\&dokument=0232_ddr\&object= translation\&l=de (dostęp: 12.06.2021).

6 Zob. m.in. L. Böhme, Die gütliche Beilegung von Rechtsstreitigkeiten vor den gesellschaftlichen Gerichten der DDR, t. 61, Göttingen 2015, s. 1.

7 W literaturze używane jest pojęcie „sądy państwowe” dla odróżnienia sądów obsadzanych w tradycyjny sposób przez sędziów zawodowych i — o ile zostało to przewidziane w odpowiednich 
pracy - ograniczana była stopniowo na rzecz społecznych organów wymiaru sprawiedliwości poprzez utworzenie specjalnych komisji. Były to komisje konfliktowe (Konfliktkommissionen $)^{8}$ i urzędy pojednawcze (Sühnestellen) ${ }^{9}$. Urzędy pojednawcze w 1964 roku zostały zastąpione przez komisje rozjemcze (Schiedskommissionen $)^{10}$. Z kolei komisje konfliktowe tworzono $\mathrm{w}$ zakładach pracy zatrudniających ponad 200 pracowników ${ }^{11}$. Od początku tej instytucji została przypisana szczególna rola w rozstrzyganiu konfliktów, ponieważ warunkiem do ewentualnego wniesienia sprawy do właściwego sądu państwowego było uzyskanie rozstrzygnięcia w postępowaniu przed komisją konfliktową ${ }^{12}$. Komisje rozjemcze ${ }^{13}$ tworzone były na wzór komisji konfliktowych działających w zakładach pracy. Ich właściwość obejmowała osiedla mieszkaniowe oraz gminy ${ }^{14}$, a także rolnicze spółdzielnie produkcyjne i spółdzielnie produkcyjne rybaków, ogrodników i rzemieślników. Zgodnie z § 5 ustawy o sądach społecznych jednej komisji nie mogło podlegać więcej niż 8 tysięcy mieszkańców.

Do kompetencji komisji konfliktowych i rozjemczych należało ściganie drobnych przestępstw oraz rozstrzyganie prostych sporów z zakresu prawa pracy oraz prawa cywilnego. W 1968 roku w drodze nowelizacji Konstytucji do systemu sądownictwa wprowadzono instytucję sądów społecznych ${ }^{15}$. W rzeczywistości nie była to nowa instytucja, ale znacząca zmiana dotychczasowej rangi komisji

przepisach - sędziów niezawodowych/ławników od wprowadzonych do systemu sądownictwa w 1968 roku sądów społecznych.

${ }^{8}$ Komisje konfliktowe utworzono na podstawie rozporządzenia Verordnung vom 30. April 1953 über die Bildung von Kommissionen zur Beseitigung von Arbeitsstreitfällen (Konfliktkommissionen) in den volkseigenen und ihnen gleichgestellten Betrieben und in den Verwaltungen, GB1. 1953, S. 695.

${ }^{9}$ Urzędy pojednawcze działały na podstawie zarządzenia Anordnung über die Errichtung von Sühnestellen in der Deutschen Demokratischen Republik (Schiedsmannsordnung) vom 24. April 1953, GB1. 1953, Nr. 59, S. 647.

10 Zastosowana w niniejszym opracowaniu terminologia odpowiada tej używanej w polskojęzycznej literaturze z okresu działania omawianych instytucji. Zob. m.in. L. Janicki, op. cit., s. 326 oraz K. Nowak, Ustrój państwowy Niemieckiej Republiki Demokratycznej, Katowice 1971, s. 208.

$11 \mathrm{~W}$ zakładach zatrudniających od 20 do 200 pracowników utworzenie komisji konfliktowych było uzależnione od porozumienia między kierownictwem zakładu pracy a kierownictwem zakładowych związków zawodowych. Zob. T. Liebscher, O. Steffen, Der Aufbau der Arbeitsgerichtsbarkeit und die Tätigkeit der Schiedsstellen für Arbeitsrecht in den neuen Bundesländern, [w:] Aufbau der Verbände und Arbeitsgerichte, red. W. Hantsche et al., Wiesbaden 1997, s. 148 n. W § 4 ustawy o sądach społecznych wskazana została liczba 300 pracowników.

12 Wymóg ten wynikał bezpośrednio z $§ 8$ rozporządzenia o komisjach konfliktowych. Zob. S. Mampel, Die sozialistische Verfassung der Deutschen Demokratischen Republik, Text und Kommentar, Frankfurt am Main 1972, s. 1072 n.

13 Podstawę prawną ich działania stanowiła dyrektywa Rady Państwa: Richtlinie des Staatsrates der Deutschen Demokratischen Republik über die Bildung und Tätigkeit von Schiedskommissionen vom 21. August 1964, GB1. I, Nr. 9, S. 115.

$14 \mathrm{~W}$ przypadku większych gmin tworzono kilka komisji rozjemczych.

15 Pojęcie „sądy społeczne” zastąpiło używany wcześniej termin „społeczne organy wymiaru sprawiedliwości”, które pozostawiono w uchwalonych także w 1968 roku kodeksie postępowania 
konfliktowych i rozjemczych. $\mathrm{Z}$ instytucji o charakterze społecznym stały się one konstytucyjnym organem wymiaru sprawiedliwości.

\section{Konstytucyjne podstawy działania sądów społecznych}

Sądy społeczne stanowiły, w myśl postanowień konstytucyjnych, integralną część systemu wymiaru sprawiedliwości i zostały wskazane jako takie w art. 92 Konstytucji NRD z 1968 roku, obok Sądu Najwyższego (Oberstes Gericht), sądów okręgowych (Bezirksgerichte) i sądów powiatowych (Kreisgerichte). Nadanie im rangi organu konstytucyjnego przyczyniło się jednocześnie do zwiększenia dotychczasowego znaczenia i roli organów społecznych dla wymiaru sprawiedliwości. De facto sądy społeczne stały się sądami najniższej instancji w systemie sądownictwa NRD. Szczegółowe zasady funkcjonowania sądów społecznych, zgodnie $\mathrm{z}$ postanowieniami konstytucyjnymi, zostały uregulowane $\mathrm{w}$ odrębnych ustawach. Najważniejszą z nich była ustawa o sądach społecznych NRD, uchwalona 11 czerwca 1968 roku $^{16}$. Ponadto odpowiednie zapisy dotyczące sądów społecznych znalazły się w postanowieniach rozdziału IV Konstytucji, regulującego socjalistyczną praworządność i wymiar sprawiedliwości, jak chociażby wspomniany we wstępie niniejszego opracowania art. 87, stanowiący o gwarancji praworządności socjalistycznej poprzez udział obywateli w wymiarze sprawiedliwości, i art. 90 ust. 3, bezpośrednio gwarantujący udział obywateli w wymiarze sprawiedliwości. W art. 94 i 95 uregulowano zasady wyboru sędziów, w tym członków ${ }^{17}$ sądów społecznych, podczas gdy art. 96 zawierał konstytucyjną gwarancję niezawisłości sędziów i członków sądów społecznych.

\section{Organizacja i funkcjonowanie sądów społecznych}

Zgodnie z postanowieniem art. 92 Konstytucji NRD szczegółowe zasady funkcjonowania sądów społecznych zostały uregulowane we wspomnianej ustawie o sądach społecznych, która po zmianach z 12 marca 1982 roku $^{18}$ obowiązywała

karnego (Strafprozessordnung der DDR) oraz kodeksie postępowania cywilnego (Zivilprozessordnung der DDR).

${ }^{16}$ Gesetz über die gesellschaftlichen Gerichte der Deutschen Demokratischen Republik vom 11. Juni 1968, GBl. 1968, S. 229, uchylona następnie ustawą o sądach społecznych z 12 marca 1982 roku: Gesetz über die gesellschaftlichen Gerichte der DDR vom 12. März 1982, GBl. 1982 I, S. 269, która weszła w życie 1 stycznia 1983 roku.

17 W wypadku sądów społecznych ustawodawca używa określenia „członkowie sądów społecznych” (Mitglieder gesellschaftlicher Gerichte), a nie „sędziowie”, które zostało zarezerwowane dla sędziów zawodowych.

18 Gesetz über die gesellschaftlichen Gerichte der Deutschen Demokratischen Republik, GBl. 1982, S. 269. 
do roku $1990^{19}$, a więc do zjednoczenia Niemiec. Odpowiednie przepisy dotyczące działania sądów społecznych zawierały także inne ustawy, takie jak: ustawa o ustroju sądów NRD ${ }^{20}$, kodeks pracy ${ }^{21}$, kodeks karny ${ }^{22}$ czy kodeks postępowania karnego ${ }^{23}$. Szczegółowe zasady działania komisji stanowiących sądy społeczne zawarte były również w uzupełniających postanowienia ustawowe regulaminach ${ }^{24}$.

\section{Pozycja sądów społecznych w systemie wymiaru sprawiedliwości i ich organizacja}

Zgodnie z postanowieniami § 1 ustawy o sądach społecznych stanowiły one integralną część jednolitego systemu socjalistycznego wymiaru sprawiedliwości i socjalistycznej demokracji. Były wybieralnymi organami, których głównym zadaniem było wychowanie i samowychowanie obywateli oraz zwalczanie i zapobieganie naruszeniom prawa, a także rozstrzyganie sporów. Ich powołanie oznaczało jednocześnie realizację konstytucyjnej gwarancji udziału obywateli w wymiarze sprawiedliwości. W $§ 2$ ust. 2 ustawy o sądach społecznych powtórzona została też konstytucyjna zasada niezawisłości ${ }^{25}$ członków sądów społecznych w orzekaniu oraz zasada ich podległości jedynie Konstytucji oraz ustawom i innym przepisom prawa Niemieckiej Republiki Demokratycznej ${ }^{26}$. Wprawdzie zarówno w Konstytucji, jak i w ustawie używana jest nazwa „sądy społeczne”, ustawodawca zachował jednak dotychczasową strukturę społecznych organów

19 Ustawa ta została w 1990 roku zastąpiona ustawą o utworzeniu i postępowaniu urzędów pojednawczych w zakresie prawa pracy: Gesetz über die Errichtung und das Verfahren der Schiedsstellen für Arbeitsrecht, GB1. 1990 I, S. 505 oraz ustawą o urzędach pojednawczych w gminach: Gesetz über Schiedsstellen in den Gemeinden vom 13. September 1990, GBl. 1990 I, S. 1527.

${ }^{20}$ Gesetz über die Verfassung der Gerichte der Deutschen Demokratischen Republik, GBl. 1963 I, S. 45 ze zmianami wynikającymi ze zmian Konstytucji NRD w 1968 oraz 1974 roku.

${ }^{21}$ Das Gesetzbuch der Arbeit der Deutschen Demokratischen Republik vom 12. April 1961, GB1. 1961 I, S. 27, kilkukrotnie zmieniany, między innymi ze względu na wprowadzenie przepisów o sądach społecznych.

22 Strafgesetzbuch der DDR vom 12. Januar 1968, GBl. 1968 I, S. 1; kilkukrotnie zmieniany, obowiązywał do zjednoczenia Niemiec 3 października 1990 roku.

23 Strafprozeßordnung der DDR vom 12. Januar 1968, GB1. 1968 I, S. 3.

${ }^{24}$ Beschluß des Staatsrates der DDR über die Tätigkeit der Konfliktkommissionen — Konfliktkommissionsordnung — vom 12. März 1982, GB1. 1982 I, S. 274 oraz Beschluß des Staatsrates der DDR über die Tätigkeit der Schiedskommissionen - Schiedskommissionsordnung — vom 12. März 1982, GB1. 1982 I, S. 283.

25 Należy przy tym pamiętać, że system powoływania sędziów i członków sądów społecznych był oparty na przynależności partyjnej. Wyboru dokonywały odpowiednie przedstawicielstwa ludowe na określony czas. Sędziowie oraz członkowie sądów społecznych podlegali obowiązkowi składania sprawozdań z wykonania swoich obowiązków i mogli w określonych sytuacjach zostać odwołani przed upływem kadencji.

26 Zob. L. Janicki, op. cit., s. 355. 
wymiaru sprawiedliwości i określił wprost w $§ 2$ ustawy o sądach społecznych, że sądami społecznymi są komisje konfliktowe i rozjemcze.

Komisje konfliktowe działały w państwowych zakładach pracy, przedsiębiorstwach państwowych i prywatnych, w instytucjach służby zdrowia, kultury i oświaty, $\mathrm{w}$ organach $\mathrm{i}$ instytucjach państwowych oraz $\mathrm{w}$ organizacjach społecznych ${ }^{27}$. Wyboru ich członków na dwuletnią kadencję dokonywali sami pracownicy na takich samych zasadach, jakie obowiązywały w przypadku wyborów w związkach zawodowych. Natomiast komisje rozjemcze były powoływane w osiedlach miejskich i gminach oraz w rolniczych, rybackich, ogrodniczych i rzemieślniczych spółdzielniach produkcyjnych ${ }^{28}$, a wyboru ich członków dokonywały lokalne przedstawicielstwa ludowe (powiatu, miasta lub dzielnicy) na wniosek komisji Frontu Narodowego, a po zmianie ustawy ${ }^{29}$ kandydatów zgłaszały partie polityczne lub organizacje społeczne albo zarządy spółdzielni produkcyjnych. W przypadku komisji działających w spółdzielniach wyboru dokonywało zgromadzenie wszystkich członków spółdzielni na wniosek jej zarządu. W związku z dokonywaniem wyboru członków komisji rozjemczych wraz z typowaniem sędziów sądów powszechnych ich kadencja także trwała cztery lata ${ }^{30}$.

Członkiem sądu społecznego mógł zostać zasłużony i przykładny pracownik danego zakładu pracy lub danej społeczności, który cieszył się zaufaniem innych obywateli i który najpóźniej w dniu wyboru ukończył 18. rok życia. Od kandydatów nie było wymagane wykształcenie prawnicze, ale podlegali oni regularnym szkoleniom. Ustawodawca przewidział też możliwość odwołania członka sądu społecznego przed upływem jego kadencji w wypadku rażącego naruszenia przez niego Konstytucji, ustaw lub wynikających z innych zapisów obowiązków. Członkowie sąów społecznych podlegali również obowiązkowi sprawozdawczości ze swojej działalności ${ }^{31}$. Możliwość odwołania oraz obowiązek sprawozdawczości były typowymi rozwiązaniami przyjętymi w demokracji ludowej i stanowiły gwarancję bezpośredniego udziału obywateli w sprawowaniu władzy. Sąy społeczne liczyły od 8 do 15 członków, w wyjątkowych sytuacjach liczba członków mogła zostać obniżona do 6 lub podwyższona do 20. Członkowie sądów społecznych wykonywali swoje zobowiązania nieodpłatnie ${ }^{32}$.

$27 \S 4$ ustawy o sądach społecznych.

$28 \S 5$ ustawy o sądach społecznych.

29 Ustawa o sądach społecznych została zmieniona w 1982 roku.

30 Ustawowe przepisy o wyborze członków sądów społecznych realizowały konstytucyjne postanowienia wynikające z art. 95 Konstytucji NRD z 1968 roku, zgodnie z którymi wybór sędziów dokonywany był przez przedstawicielstwa ludowe lub bezpośrednio przez obywateli.

31 Te regulacje ustawowe także znajdowały swoją podstawę w art. 95 Konstytucji. Zob. L. Janicki, op. cit., s. 355 oraz K. Nowak, op. cit., s. 208.

${ }^{32}$ Zob. B.C. Peters, Der Gütegedanke im deutschen Zivilprozeßrecht - eine historisch - soziologische Untersuchung zum Gütegedanken im Zivilverfahrensrecht seit 1879, Jena 2004, s. 149. 


\section{Właściwość rzeczowa i postępowanie przed sądami społecznymi}

Do ustawowo określonych kompetencji sądów społecznych należały sprawy z zakresu prawa pracy, występki ${ }^{33}$, uchybienia, wykroczenia, naruszenia obowiązku szkolnego, unikanie pracy, a także proste spory z zakresu prawa cywilnego $^{34}$ między obywatelami oraz między pracownikami a zakładem pracy. Ponadto sądy społeczne rozstrzygały inne sprawy, które zostały im przekazane przez prokuraturę lub sądy, jeżeli wynikało to z innych ustaw.

Sądy społeczne rozstrzygały powierzone im sprawy kolegialnie, w składzie co najmniej 4 członków. Posiedzenia miały charakter jawny, a wszystkie uczestniczące $\mathrm{w}$ nich osoby miały prawo do zabrania głosu w sprawie $\mathrm{i}$ - poprzez zadawanie pytań lub udzielanie wskazówek - do bezpośredniego współuczestniczenia w rozwiązywaniu konfliktu. Zarówno wnioskodawca, jak i strona przeciwna lub obwiniony byli zobowiązani do osobistego stawiennictwa przed sądem społecznym oraz mieli prawo do skorzystania z porad prawnych związków zawodowych, sądów powiatowych lub adwokata.

Sądy społeczne działały w sposób dość swobodny, nie były związane ustalonymi ustawowo procedurami, jak miało to miejsce $\mathrm{w}$ wypadku postępowań przed sądami powszechnymi ${ }^{35}$. Orzeczenia były wydawane albo $w$ formie uchwały (Beschlu $\beta$ ) w sprawie dochodzonego roszczenia (w przypadku spraw z zakresu prawa pracy), albo potwierdzeniem (Bestätigung) porozumienia/ugody między stronami (w wypadku spraw z zakresu prawa cywilnego) lub występku, uchybienia, wykroczenia, naruszenia obowiązku szkolnego lub uchylania się od pracy. Celem postępowań toczących się przed sądami społecznymi było przede wszystkim osiągnięcie porozumienia między stronami sporu.

${ }^{33}$ Na przykład drobne kradzieże, przestępstwa przeciwko socjalistycznej lub osobistej własności, uszkodzenie ciała, naruszenie miru domowego - w wypadku przestępstw uregulowanych w kodeksie karnym o przekazaniu sprawy do rozstrzygnięcia sądom społecznym decydowały prokuratura i policja. Zob. m.in. A. Eser, Gesellschaftsgerichte in der Strafrechtspflege: neue Wege zur Bewältigung der Kleinkriminalität in der DDR, Recht und Staat in Geschichte und Gegenwart, Nr. 388/389, Tübingen 1970, s. 28 n.

34 Na przykład sprawy roszczeń pieniężnych, ustalonych zobowiązań alimentacyjnych, spory dotyczące naruszenia praw i obowiązków powstałych we wspólnotach mieszkaniowych o wartości przedmiotu sporu do wysokości 1000 marek. Zakres kompetencji sądów społecznych wynikał z postanowień ustawy o sądach społecznych oraz z regulaminów komisji konfliktowych i komisji rozjemczych. Zob. m.in. B.C. Peters, op. cit., s. 149 n. oraz T. Feltes, Gesellschaftliche Gerichte, Schlichtungs- und Schiedskommissionen - Rechtspolitische Möglichkeiten oder historische Irrtümer, s. 5, https://www.thomasfeltes.de/pdf/veroeffentlichungen/1991_GesellschaftlicheGerichte. pdf (dostęp: 24.09.2021).

35 Zob. S. Mampel, op. cit., s. 1080 oraz W. Belehrt, Organisation und sozialer Status der Richter und Rechtsanwälte in der DDR, „Kritische Justiz” 1991, z. 2, s. 185 n. 
Sankcjami ${ }^{36}$ stosowanymi przez sądy społeczne były tak zwane środki wychowawcze w formie: przeprosin pokrzywdzonego w obecności kolektywu zakładu pracy, naprawienia szkody poprzez zapłatę konkretnej kwoty pieniężnej lub świadczenie konkretnej pracy, nieodpłatna praca społeczna w wymiarze do 20 godzin ${ }^{37}$, nałożenie innych zobowiązań mających na celu osiągnięcie zachowania zgodnego z prawem, udzielenia nagany, kary grzywny w wysokości od 10 do 500 marek $^{38}$, a w przypadku znieważenia - jego wycofania w odpowiedniej formie. $\mathrm{W}$ przypadku stwierdzenia popełnienia czynu niewielkiej wagi, uwzględniając zachowanie sprawcy po jego popełnieniu lub w przypadku starań podjętych przez sprawcę, mających na celu naprawienie szkody lub gdy jego zachowanie pozwalało oczekiwać, że w przyszłości będzie przestrzegał socjalistycznego prawa, sąd społeczny mógł odstapić od zastosowania środków wychowawczych.

Sądy społeczne, oprócz rozstrzygania spraw należących do ich właściwości, miały prawo do udzielania zaleceń (Empfehlungen) ${ }^{39}$ zakładom pracy, instytucjom społecznym czy państwowym, jeżeli w toku postępowania stwierdziły nieprawidłowości w ich działaniu. Udzielanie zaleceń miało charakter działań prewencyjnych.

Wprawdzie większość postępowań przed sądami społecznymi kończyła się na wydaniu przez nie odpowiedniego orzeczenia, jednak nie były one ostateczna instancją. Zgodnie z postanowieniami § 19 ustawy o sądach społecznych od ich orzeczeń stronom przysługiwało prawo do złożenia sprzeciwu do sądu powiatowego.

\section{Uwagi końcowe}

Sądy społeczne funkcjonowały do zjednoczenia Niemiec w 1990 roku i odgrywały istotną rolę w systemie sądownictwa NRD. W 1989 roku, a więc krótko przed zawieszeniem działalności sądów społecznych, działało 29300 komisji konfliktowych, w których pracowało 258 tysięcy członków, oraz 5800 komisji rozjemczych z 57 tysiącami członków ${ }^{40}$. Ogółem w działalność sądów społecznych zaangażowane było około $2 \%$ ogółu społeczeństwa NRD. W okresie swojego działania sądy społeczne rozpatrywały rocznie po kilkadziesiąt spraw wynikających z naruszenia przepisów prawa ${ }^{41}$.

36 Zob. § 20 ustawy o sądach społecznych (w wersji z 1982 roku) oraz regulaminy postępowania przed komisjami konfliktowymi i komisjami rozjemczymi.

37 Sankcja wprowadzona w drodze nowelizacji ustawy o sądach społecznych w 1982 roku.

38 Górna granica kary grzywny początkowo wynosiła 150 marek.

39 Zob. § 21 ustawy o sądach społecznych z 1982 roku.

40 FDGB-Lexikon, Berlin 2009, http://library.fes.de/FDGB-Lexikon/texte/sachteil/g/Gesell schaftliche_Gerichte.html (dostęp: 24.09.2021); według danych innych autorów działały 26744 komisje konfliktowe i 5552 komisje rozjemcze, w których pracowało łącznie około 300 tysięcy osób; zob. T. Feltes, op. cit., s. 4.

41 T. Feltes, op. cit., s. 5 n. 
Z perspektywy władz NRD sądy społeczne były oceniane w kategoriach sukcesu, ponieważ realizowały socjalistyczną zasadę bezpośredniego wpływu i udziału obywateli w sprawowaniu władzy w państwie. W zasadzie przedstawiciele ludu pracującego miast i wsi ${ }^{42} \mathrm{w}$ ramach działalności sądów społecznych przejęli jedną z podstawowych funkcji organów państwowych, jaką jest sprawowanie wymiaru sprawiedliwości. Było to $\mathrm{z}$ pewnością zgodne z zasadami socjalistycznej demokracji ludowej, jednak oceniając to rozwiązanie z perspektywy czasu, przede wszystkim daje się zauważyć, że faktycznym celem sądów społecznych było publiczne napiętnowanie osób, które dopuszczały się naruszeń socjalistycznego prawa, i miało przynieść efekt odstraszający. Rozpatrywanie spraw przez ,społecznych sędziów” pochodzących z najbliższego otoczenia zawodowego lub społecznego sprawcy i politycznego wyboru oraz możliwość sugerowania rozwiązania przez inne osoby uczestniczące w postępowaniu z pewnością nie gwarantowało niezawiłości w orzekaniu. Z dzisiejszej perspektywy sądom społecznym można by przypisać jedynie charakter symboliczny.

\section{Bibliografia}

Belehrt W., Organisation und sozialer Status der Richter und Rechtsanwälte in der DDR, „Kritische Justiz" 1991, z. 2.

Böhme L., Die gütliche Beilegung von Rechtsstreitigkeiten vor den gesellschaftlichen Gerichten der $D D R$, t. 61, Göttingen 2015.

Eser A., Gesellschaftsgerichte in der Strafrechtspflege: neue Wege zur Bewältigung der Kleinkriminalität in der DDR, Recht und Staat in Geschichte und Gegenwart, Nr. 388/389, Tübingen 1970.

FDGB-Lexikon, Berlin 2009, http://library.fes.de/FDGB-Lexikon/texte/sachteil/g/Gesellschaftliche_Gerichte.html.

Feltes T., Gesellschaftliche Gerichte, Schlichtungs- und Schiedskommissionen - Rechtspolitische Möglichkeiten oder historische Irrtümer, https://www.thomasfeltes.de/pdf/veroeffentlichungen/1991_GesellschaftlicheGerichte.pdf.

Fragen zur DDR - Verfassung im Vergleich mit dem Grundgesetz, https://www.bundestag.de/resource/blob/422898/cd5058f62cb62fd679b49ff115b5fc51/wd-3-151-09-pdf-data.pdf.

Janicki L., Ewolucja ustroju politycznego Niemieckiej Republiki Demokratycznej, Wrocław 1974.

Kleines kriminologisches Wörterbuch. 2. völlig neubearbeitetet und erweiterte Auflage, red. G. Kaiser, Heidelberg 1985.

Liebscher T., Steffen O., Der Aufbau der Arbeitsgerichtsbarkeit und die Tätigkeit der Schiedsstellen für Arbeitsrecht in den neuen Bundesländern, [w:] Aufbau der Verbände und Arbeitsgerichte, red. W. Hantsche, S. Otte, G. Hoffmann, T. Liebscher, O. Steffen, Wiesbaden 1997.

Mahnke H., Menschen- und Grundrechte in beiden Teilen Deutschlands, „Vereinte Nationen: German Review on the United Nations" 17, 1969, nr 1.

Mampel S., Die sozialistische Verfassung der Deutschen Demokratischen Republik, Text und Kommentar, Frankfurt am Main 1972.

Nowak K., Ustrój państwowy Niemieckiej Republiki Demokratycznej, Katowice 1971.

42 Takie było konstytucyjne określenie suwerena w art. 1 Konstytucji NRD z 1968 roku. 
Peters B.C., Der Gütegedanke im deutschen Zivilprozeßrecht - eine historisch - soziologische Untersuchung zum Gütegedanken im Zivilverfahrensrecht seit 1879, Jena 2004.

Szczemielinow P., Sądy koleżeńskie w ZSRR $i$ w Federacji Rosyjskiej, „Palestra” 1961, nr 11, https://bazhum.muzhp.pl/media/files/Palestra/Palestra-r2003-t47-n1_2(541_542)/Palestra -r2003-t47-n1_2(541_542)-s108-110/Palestra-r2003-t47-n1_2(541_542)-s108-110.pdf.

\section{Akty prawne}

Konstytucja Niemieckiej Republiki Demokratycznej, wydanie zespołowe wydawnictwa Staatsverlag der Deutschen Demokratischen Republik i wydawnictwa Zeit im Bild, thumaczenie: Intertext Berlin, Dresden 1968.

Verfassung der Deutschen Demokratischen Republik vom 7. Oktober 1949, GB1. 1949 I, S. 5, https://www.1000dokumente.de/index.html?c=dokument_de\&dokument=0232_ddr\&objec$\mathrm{t}=$ translation\&l$=\mathrm{de}$.

Anordnung über die Errichtung von Sühnestellen in der Deutschen Demokratischen Republik (Schiedsmannsordnung) vom 24. April 1953, GBl. 1953, Nr. 59, S. 647.

Verordnung vom 30. April 1953 über die Bildung von Kommissionen zur Beseitigung von Arbeitsstreitfällen (Konfliktkommissionen) in den volkseigenen und ihnen gleichgestellten Betrieben und in den Verwaltungen, GB1. 1953, S. 695.

Das Gesetzbuch der Arbeit der Deutschen Demokratischen Republik vom 12. April 1961, GB1. 1961 I, S. 27.

Gesetz über die Verfassung der Gerichte der Deutschen Demokratischen Republik, GB1. 1963 I, S. 45.

Richtlinie des Staatsrates der Deutschen Demokratischen Republik über die Bildung und Tätigkeit von Schiedskommissionen vom 21. August 1964, GBl. I, Nr. 9, S. 115.

Verfassung der DDR vom 6. April 1968, GBl. 1968 I, S. 199, http://www.verfassungen.de/ddr/verf 68-i.htm.

Gesetz über die gesellschaftlichen Gerichte der Deutschen Demokratischen Republik vom 11. Juni 1968, GB1. 1968, S. 229.

Gesetz über die gesellschaftlichen Gerichte der DDR vom 12. März 1982, GB1. 1982 I, S. 269.

Beschluß des Staatsrates der DDR über die Tätigkeit der Konfliktkommissionen - Konfliktkommissionsordnung — vom 12. März 1982, GBl. 1982 I, S. 274.

Beschluß des Staatsrates der DDR über die Tätigkeit der Schiedskommissionen — Schiedskommissionsordnung — vom 12. März 1982, GBl. 1982 I, S. 283.

Gesetz über die Errichtung und das Verfahren der Schiedsstellen für Arbeitsrecht, GBl. 1990 I, S. 505.

Gesetz über Schiedsstellen in den Gemeinden vom 13. September 1990, GB1. 1990 I, S. 1527.

Strafgesetzbuch der DDR vom 12. Januar 1968, GB1. 1968 I, S. 1.

Strafprozeßordnung der DDR vom 12. Januar 1968, GBl. 1968 I, S. 3. 